Perilaku dan Budaya Konsumen Madura

dalam Dinamika Etika Bisnis Syariah

\title{
PERILAKU DAN BUDAYA KONSUMEN MADURA DALAM DINAMIKA ETIKA BISNIS SYARIAH
}

\section{Abstraksi}

Dinamika budaya di masyarakat memunculkan pola dan aktivitas ekonomi, seperti industri, mekanisme pasar, hingga pada perlindungan konsumen dalam persaingan pasar Salah satu nilai budaya lainnya yang tak kalah penting pada orang Madura adalah bahwa kesopanan dijunjung tinggi. Masyarakat Madura yang sensitif dan fanatik terhadap nilai-nilai keagamaan; seperti kesopanan, saling menghormati, serta suka tolong-menolong berdampak konstruktif dengan nilai-nilai yang terkandung dalam prinsip-prinsip etika bisnis syariah. Prinsip-prinsip bisnis Islami baik secara individu atau kelembagaan mengajak pada nilai-nilai professionalitas, kejujuran (amanah), persaudaraan dan keadilan, serta dilarang monopoli dan praktek riba. Untuk itu akan sedikit dibahas dalam tulisan kali ini mengenai perilaku orang madura terhadap etika bisnis syariah

Keyword: abhantal syahadat, asapo' iman, apajung Allah

Mashudi

Dosen Fak. Syariah STAI Darul Hikmah Bangkalan mashudi.smart@gmail.com 


\section{Mashudi}

\section{A. Pendahuluan}

Manusia adalah sebagai mahluk pilihan yang dibekali kemampuan oleh Allah SWT untuk mengelola sumber daya yang ada, mulai dari sumber daya yang melekat pada diri manusia itu sendiri maupun sumber daya yang disediakan oleh lingkungan sekitarnya. Predikat sebagai khalifah di muka bumi adalah merupakan gelar fitrah yang diamanatkan oleh Sang Maha Pencipta kepada hambanya yang bernama manusia. Predikat khalifah itu pula yang telah mewajibkan kita sebagai makhluk pilihan untuk senantiasa mengembangkan daya kreatifitas menuju pendayagunaannya yang optimal.

Dalam mengembangkan dan mengoptimalkan sumber daya yang ada ini kita tentu tidak serta merta dapat berbuat sekehendak hati kita masing-masing. Kita diikat dalam sebuah tatanan keharmonisan antara yang satu dengan yang lainnya, dengan lingkungan sekitar, serta dengan semua sistem nilai-nilai yang mengatur hubungan interaksi sosial yang dianut dan dipercaya kebenarannya. Kita harus dapat saling memelihara nilai-nilai kebenaran tersebut agar dapat menjaga kesinambungan di dalam sistem tersebut. Pengaturan hubungan yang baik dan yang buruk di dalam interaksi sosial itu disebut sistem etika.

Pada sisi lainnya, wacana keislaman di Indonesia dalam beberapa dekade belakangan semakin dinamis, karena didukung oleh perkembangan ilmu pengetahuan dan teknologi yang semakin berkembang pesat di dalam masyarakat kita. Perkembangan pengetahuan dan teknologi itu juga telah membawa pada perkembangan pengkajian keagamaan yang semakin kompleks dan variatif, seperti misalnya pemikiran tentang etika bisnis global.

Penentuan etika yang dianggap baik atau buruk mungkin saja berbeda antara suatu kelompok dengan kelompok yang lainnya. Hal itu dikarenakan beberapa perbedaan seperti masalah persepsi dan budaya yang berpengaruh kepada perbedaan perilaku masingmasing. Terdapat dua pendekatan teori kekuatan dari faktor yang mempengaruhi perilaku, yaitu kekuatan kelompok (teori sosial), dan teori motif psikologi individu. ${ }^{1}$ Masing-masing kekuatan baik dari aspek psikologis individu maupun kekuatan pengaruh

\footnotetext{
${ }^{1}$ Anwar Prabu Mangkunegara, Perilaku Konsumen, edisi revisi (Bandung: Refika
} Aditama, 2012), 40 - 41. 
Perilaku dan Budaya Konsumen Madura

dalam Dinamika Etika Bisnis Syariah

kelompok sosial akan saling mengisi persepsi seseorang. Pada akhirnya, masing-masing persepsi individu ini juga akan membentuk persepsi sosial yang diyakini kebenarannya terhadap suatu objek permasalahan.

Demikian juga halnya dalam objek kajian etika bisnis syariah dari sisi pendekatan perilaku dan budaya konsumen. Kita telah banyak menyimak tulisan atau diskusi-diskusi tentang etika bisnis syariah. Meski demikian, pada akhirnya dari sekian pembahasan itu lebih menekankan kepada aspek aturan universalnya yang telah jelas di dalam Al-Qur'an dan Al-Hadist. Dalam tulisan ini penyusun akan menyajikan bahasan terkait data-data pustaka deskriptif tentang hubungan motif-motif tersebut di dalam menjelaskan etika bisnis syariah. Tulisan ini diharapkan menjadi pengantar data deskriptif untuk menjelaskan penelitian-penelitian lain yang lebih detail dan kongkrit dengan penyajian data-data hasil analisis kuantitatif kualitatif.

\section{B. Perilaku Konsumen}

Perilaku konsumen didefinisikan sebagai kegiatan, tindakan, serta proses psikologis yang mendorong tindakan tersebut pada saat sebelum memutuskan membeli, ketika membeli, menggunakan produk atau jasa. ${ }^{2}$ Kegiatan atau tindakan melalui proses psikologis individu tersebut dapat juga dilakukan oleh kelompok sosial tertentu. Oleh karena itu model pembahasan perilaku konsumen sangat erat kaitannya dengan dua hal dimensi perilaku, yaitu: ${ }^{3}$

1. Perbedaan individu

Karakteristik dan proses psikologis individu yang muncul di dalam diri konsumen yaitu meliputi agama, kebutuhan dan motivasi, kepribadian, dan pengetahuan.

2. Faktor lingkungan

Faktor lingkungan adalah faktor di luar diri individu konsumen itu sendiri. Faktor-faktor tersebut antara lain; budaya, karakteristik sosial ekonomi, keluarga, dinamika lingkungan dan teknologi.

\footnotetext{
${ }^{2}$ Ujang Suwarman, Perilaku Konsumen: Teori dan Penerapannya dalam Pemasaran (Bandung: Ghalia Indonesia, 2015), 6.

${ }^{3}$ Ibid., 10 - 14.
} 
Kedua aspek dimensi di atas dalam prakteknya akan saling mempengaruhi konsep konsumen dalam mempersepsikan pandangannya terhadap suatu produk beserta nilai-nilai atribut yang melekat pada produk atau jasa tersebut. Dalam hal perbedaan kepribadian dan agama misalnya, maka konsumen yang berkepribadian baik dengan keyakinan agama yang kuat, tentu akan menilai suatu produk atau jasa dari sisi nilai-nilai pertimbangan yang sesuai kepribadiannya, menilai produk atau jasa juga dari sisi kebaikan dan kebenaran atas dasar agama yang terpatri dalam hatinya.

Berbeda dengan konsumen yang berkepribadian negatif dan tidak didukung oleh keimanan yang kuat terhadap agamanya, maka akan cenderung menilai suatu produk beserta atributatributnya tanpa mengindahkan pertimbangan baik atau buruk, benar atau salah berdasarkan hati nurani dan agamanya, melainkan mudah dipengaruhi faktor-faktor lain di luar itu.

Demikian juga halnya dengan kebutuhan dan motivasi, serta aspek pengetahuan. Konsumen yang mempunyai motivasi yang kuat terhadap tingkat kebutuhan tertentu, maka dalam persepsinya akan lebih toleran terhadap produk serta atribut-atribut produk yang mendukung kemudahan dalam memenuhi kebutuhannya itu. ${ }^{4}$ Sedangkan konsumen yang didukung oleh proses belajar dan pengetahuan yang luas tentang beberapa alternatif produk serta atributnya, maka konsumen tingkatan ini akan lebih selektif dan penuh pertimbangan.

Pada perkembangan selanjutnya, konsumen pada tingkatan telah berproses belajar dan berpengetahuan ini akan menyukai produk dan atribut produk tertentu dan memilih loyal padanya. Pemasar perlu memahami bagaimana konsumen belajar, karena pemasar berkepentingan untuk mengajarkan konsumen agar konsumen dapat mengenali atribut produknya, mengingatnya, dan membeli produk yang dipasarkannya. Proses belajar konsumen adalah bagian penting dari kegiatan konsumen yang dilakukannya secara sadar maupun tidak sengaja. ${ }^{5}$

\footnotetext{
${ }^{4}$ N.J. Setiadi, Perilaku Konsumen: Konsep dan Implikasinya untuk Strategi dan Penelitian Pemasaran (Jakarta: Prenada Media, 2003), 11.

${ }^{5}$ Ujang Suwarman, Perilaku Konsumen: Teori dan Penerapannya dalam Pemasaran, 117.
} 
Perilaku dan Budaya Konsumen Madura

dalam Dinamika Etika Bisnis Syariah

Konsumen yang kecewa karena telah salah mempersepsikan dan memilih produk atau atributnya, akan memiliki pengalaman yang buruk dan persepsi negatif terhadap produk tersebut. Ketika hal itu terjadi, maka proses belajar pada diri konsumen berlangsung. Pengalaman ini akan memberikan pelajaran kepada diri konsumen, yang akan mempengaruhi keputusan pembelian produk tersebut di masa yang akan datang. Produk tersebut beserta atribut-atributnya mungkin tidak akan disukainya lagi, tidak akan dibeli lagi. Bahkan konsumen mungkin akan menyampaikan kekecewaan terhadap produk tersebut kepada teman, kerabat, serta orang-orang di sekelilingnya. Ketidakpuasan seorang konsumen itu pada akhirnya akan diikuti oleh persepsi orang-orang di sekitarnya. Itulah yang telah disampaikan oleh penulis pada pendahuluan tulisan ini, yaitu persepsi individu yang membentuk persepsi sosial.

\section{Budaya, Agama dan Perilaku Konsumen}

Riset yang telah dilakukan oleh beberapa ahli seperti Setiadi, Anwar Prabu Mangkunegara, dan Ujang Suwarman menunjukkan bahwa faktor-faktor yang mempengaruhi persepsi dan perilaku selain dari dalam diri konsumen itu sendiri, juga dikuatkan oleh faktor dari luar (faktor lingkungan). Karakteristik sosial ekonomi, keluarga, dinamika lingkungan dan teknologi, serta unsur budaya adalah merupakan faktor-faktor dari luar yang mempengaruhi perilaku konsumen.

Menurut Anwar, budaya didefinisikan sebagai hasil kreativitas manusia dari satu generasi ke generasi berikutnya yang sangat menentukan bentuk perilaku dalam kehidupannya sebagai anggota masyarakat. ${ }^{6}$ Kebudayaan juga dapat dipandang sebagai sesuatu yang kompleks yang meliputi ilmu pengetahuan, kepercayaan, seni, moral, adat istiadat, serta semua norma-norma yang berlaku di masyarakat.

Menurut Ujang Suwarman, selain unsur pendidikan, setidaknya ada (empat) unsur pendukung yang sangat mempengaruhi budaya, yaitu ${ }^{7}$

1. Nilai (termasuk di dalamnya ajaran agama).

\footnotetext{
${ }^{6}$ Anwar Prabu Mangkunegara, Perilaku Konsumen, edisi revisi, 39.

${ }^{7}$ Ujang Suwarman, Perilaku Konsumen: Teori dan Penerapannya dalam Pemasaran, 228,230 .
} 
2. Norma-norma yang diyakini oleh setiap individu dalam kelompok.

3. Mitos (kepercayaan terhadap cerita-cerita tanpa penelusuran lebih jauh terkait kebenarannya).

4. Simbol (objek atau konsep yang memiliki arti penting dan sakral).

Budaya dalam makna yang khusus memiliki konsep-konsep abstrak tentang hubungan tata sosial yang pada mulanya berasal dari kebiasaan sehari-hari dari tradisi suatu kelompok masyarakat yang mentradisi. Tata sosial ini diterima secara umum oleh dominasi masyarakat dan kemudian terlembaga menjadi nilai sosial dengan standar-standar yang berlaku umum. Nilai budaya ini merupakan hasil hubungan timbal balik antara nilai realitas kehidupan sosial dan kemasyarakatan yang selalu berkembang.

Menurut Burhan Bungin, perkembangan konsep tentang kebudayaan kontemporer, kebudayaan universal memiliki unsurunsur penting lain yang lebih luas, sebagaimana berikut: ${ }^{8}$

a. Sistem teknologi;

b. Sistem mata pencaharian hidup (sistem ekonomi-produksi);

c. Sistem sosial;

d. Sistem bahasa;

e. Sistem kesenian;

f. Sistem pengetahuan;

g. Sistem religi;

h. Sistem pertahanan dan kekuasaan;

i. Sistem norma dan aturan;

j. Sistem pendidikan;

k. Sistem kesehatan;

Tidak dapat dipungkiri bahwa tiap-tiap nilai dalam masingmasing sistem yang menyangkut penilaian baik dan buruk atas suatu perilaku dan tindakan dalam kehidupan masyarakat akan menjadi norma sosial. Bentuk norma-norma sosial yang menjadi budaya tersebut mungkin saja berbeda antara suatu bangsa dengan bangsa lainnya, antara suku tertentu dengan suku lainnya, dan

${ }^{8}$ H.M. Burhan Bungin, Sosiologi Komunikasi (Jakarta: Prenada Media, 3013), 54. 
Perilaku dan Budaya Konsumen Madura

dalam Dinamika Etika Bisnis Syariah

mungkin saja bahkan sangat kontras antara budaya-budaya tersebut.

Berdasarkan pengertian budaya dan unsur-unsur pembentuknya, maka budaya dalam konteks ini dianggap merujuk pada semua faktor sosial, politik, dan faktor lain yang mempengaruhi perilaku individu. Oleh karena itu agama dianggap termasuk salah satu faktor budaya. Agama memiliki potensi untuk diterima bukan saja di suatu negara tetapi bahkan melampaui negara. Suatu faktor yang rumit ini, sepertinya membingungkan karena menjelaskan analisis atas hal-hal yang berkaitan antara nilai-nilai kepercayaan antara benar dan salah yang melibatkan sifat lokal suatu daerah atau negara.

Dalam banyak analisis, harmonisasi antara unsur agama sebagai salah satu pembentuk budaya dengan pandangan umum tentang kebenaran yang bersifat subjektif adalah cenderung terdikotomi. $^{9} \quad$ Manakala pembahasan tentang kebudayaan dihadapkan pada kebenaran universal sebagai sifat nurani dari kebenaran itu sendiri, seringkali diwarnai oleh faktor-faktor yang bersifat egosentrik pribadi atau kelompok. Oleh karena itu penggunaan dan konsep yang ingin dicapai lebih kepada masalah jurisdiksi dan proses politik daripada upaya memperjelas filosofinya.

Pada perkembangannya, di beberapa negara Islam, kesulitankesulitan yang timbul akibat tekanan pandangan politik baik dari dalam negeri atau luar negeri, dilipatgandakan dengan tambahan tuntutan-tuntutan agama yang seringkali dilembagakan sehingga memunculkan konflik kepentingan. Agama dianggap sebagai objek sekaligus subjek yang sensitif, sehingga seringkali digunakan sebagai kedok bagi aktivitas-aktivitas di luar kepentingan agama. ${ }^{10}$

Pengertian agama sendiri adalah merupakan istilah yang berasal dari dua suku kata dalam bahasa Sanskerta, yaitu $a$ yang berarti tidak, dan gama yang berarti kacau. Agar suatu tatanan tidak kacau, maka dibutuhkan sistem tata nilai yang menunjukkan

\footnotetext{
${ }^{9}$ Sofyan Syafri Harahap, Akuntansi Islam (Jakarta: Bumi Aksara, 2001), 205.

${ }^{10}$ Ibrahim Warde, Islamic Finance: Keuangan Islam dalam Perekonomian Global Penerj.Andriyadi Ramli (Yogyakarta: Penerbit Pustaka Pelajar, 2009), 389.
} 
kepada nilai-nilai hubungan ketuhanan, nilai-nilai kebaikan universal, serta nilai-nilai kebenaran mutlak.

Dalam hal agama sebagai salah satu nilai pembentuk budaya, maka Islam hadir sebagai nilai. Islam mengajarkan etika hubungan ketuhanan, Islam juga mengajak kepada nilai-nilai kebaikan dan kebenaran. Kebaikan dan kebenaran yang terkandung dalam ajaran Islam adalah bersifat universal sesuai dengan hakikat kebutuhan manusia itu sendiri. Dalam pengertian lainnya yaitu bahwa ajaran Islam dapat diterima oleh semua manusia manakala manusia kembali kepada hakikat kemanusiaannya.

Hubungan antara perilaku manusia dengan budaya dalam konteks keyakinan beragama dapat kita simak pada firman Allah SWT di dalam Surat ar-Rum ayat 9, yaitu:

Apakah mereka tidak mengadakan perjalanan di muka bumi dan memperhatikan bagaimana akibat yang diderita oleh orang-orang yang sebelum mereka? Orang-orang itu adalah lebih kuat dari mereka sendiri dan telah mengolah bumi serta memakmurkannya lebih banyak dari apa yang telah mereka makmurkan, dan telah datang kepada mereka Rasul-Rasul mereka dengan membawa bukti-bukti yang nyata. Maka Allah sekali-kali tidak berlaku zalim kepada mereka, akan tetapi merekalah yang berlaku zalim kepada mereka sendiri".

Firman Allah di atas mengajarkan dua metodologi penting dalam penelitian kebaikan dan kebenaran. Metode historical reality dan alegori (tamsil) bahwa kelompok manusia yang beretika ketuhanan dan kelompok penentang pada sisi yang lainnya.

Berdasarkan ayat tersebut dijelaskan bahwa untuk mendapatkan kebenaran dan kebaikan, maka kita dapat belajar dari data empiris (sejarah). Melalui fakta sejarah kita dapat menggali beberapa informasi tentang perilaku manusia beserta konsekuensi dari perilaku tersebut. Penelitian tentang perilaku manusia inilah selanjutnya kita kenal dengan istilah pendekatan perilaku. Jika yang sedang kita bahas dalam tulisan ini adalah tentang perilaku konsumen maka berarti pendekatan yang digunakan adalah penggalian informasi yang berkaitan dengan perilaku konsumen. 
Perilaku dan Budaya Konsumen Madura

dalam Dinamika Etika Bisnis Syariah

Selama ini tidak dapat dipungkiri bahwa pembahasan perilaku konsumen selalu berkaitan dengan proses pengambilan keputusan pembelian. Bagi konsumen muslim proses pengambilan keputusan pembelian dan penggunaan produk atau jasa dapat pula berkembang kepada pertimbangan unsur perilakunya sebagai muslim yang taat pada agamanya. Kebutuhannya untuk mendapatkan produk atau atribut yang sesuai dengan prinsip etika keagamaan justru kadang terabaikan oleh pihak perusahaan.

Oleh karena itu bagi perusahaan yang mengembangkan sistem komunikasi pemasaran pendekatan konsep konsumen, tidak mungkin perhatiannya akan melupakan keterlibatan persepsi konsumen, bahkan harus didukung dan dikembangkan melalui atribut-atribut produk atau jasa yang diproduksi. Sehingga etika bukan hanya merupakan aturan-aturan ideal dan normatif akan tetapi melekat pada produk atau jasa sebagai atributnya.

Dalam kegiatan bisnis bernuansa Islami, pembudayaan kepercayaan (trust) dimulai dari dalam individu seseorang, dan kemudian membentuk suatu kepercayaan dengan orang lain. ${ }^{11}$ Untuk membangun kepercayaan yang kuat maka perlu dibangun komunikasi intensif antara pihak produsen dengan pihak pasar atau konsumen. Membangun komunikasi yang dimaksud tidak hanya dalam pelayanan penjualan tetapi juga secara menyeluruh pada segenap aspek kegiatan produksi barang atau jasa beserta atributatributnya.

\section{Budaya Madura dan Dinamika Etika Bisnis Syariah}

Literatur Islam yang ada sekarang mengenai ekonomi mempergunakan dua macam metode, yaitu metode deduksi dan metode pemikiran retrospektif. Metode deduksi dikembangkan oleh para ahli ekonomi Islam dan fuqaha. Metode ini diaplikasikan terhadap ekonomi Islam modern untuk menampilkan prinsipprinsip sistem Islam dan kerangka hukumnya dengan berkonsultasi dengan sumber-sumber Islam, yaitu al-Qur'an dan as-Sunnah. Adapun metode pemikiran retrospektif dipergunakan oleh banyak penulis muslim kontemporer yang merasakan tekanan kemiskinan dan keterbelakangan di dunia Islam serta berusaha mencari berbagai pemecahan terhadap persoalan-persoalan ekonomi umat muslim dengan kembali kepada al-Qur'an dan as-Sunnah untuk

${ }^{11}$ Ika Yunia Fauzia, Etika Bisnis dalam Islam (Jakarta: Prenada Media, 2013), 143 


\section{Mashudi}

mencari dukungan atas pemecahan-pemecahan tersebut dan mengujinya dengan memperhatikan petunjuk Tuhan. ${ }^{12}$

Pendekatan metode kedua di atas sejalan dengan naluriah kemanusiaan dengan potensi akal dan pikirannya, yaitu tidak pernah menerima sesuatu sebagai realitas yang selesai atau statis. Manusia selalu melibatkan dirinya dalam usaha merancang masa depan dirinya, baik itu secara individu maupun secara kolektif. Usaha tersebut diwujudkan melalui ilmu pengetahuan dan perangkat pendukung lainnya. Manusia sebagai makhluk berakal selalu menggunakan realitas lingkungan kehidupannya sebagai wahana atau ruang untuk berimprovisasi dan berinovasi terhadap berbagai kemungkinan yang bertujuan untuk mengubah kondisi, baik kondisi dirinya maupun lingkungannya.

Manusia akan selalu mencari sesuatu yang baru dalam usaha mengembangkan lingkungan hidupnya, sesuai dengan tuntutan budaya dan peradaban. Berdasarkan nalarnya, manusia dapat mengembangkan sistem nilai yang telah ada. Dalam kenyataan ini jelas bahwa manusia mempunyai keterbatasan diri, yaitu tidak bisa menciptakan standar nilai atau etika. ${ }^{13}$ Kecenderungan manusia untuk mengembangkan diri pada nilai-nilai ideal, yakni kesadaran pada etika dan moralitas (agama) akan membentuk suatu tatanan kehidupan, baik secara individu atau berkelompok. Dengan demikian hal ini akan memberi kualitas dalam menentukan arah dan pola kehidupan masyarakat dalam lingkungan hidupnya.

Interaksi nilai sosial sebenarnya sudah disadari sejak beberapa abad dahulu kala oleh seorang filusuf muslim al-Imam Abu Ali Ahmad Miskawih. Dalam bahasannya, beliau menyampaikan bahwa manusia sanggup meningkatkan kesalihannya dengan melalui pembauran dengan masyarakat serta berbagi suka dan duka dengan mereka. Kualitas luhur orang lain dapat dikembangkan secara kolektif dengan hidup bekerja sama dengan orang lain. ${ }^{14}$

\footnotetext{
${ }^{12}$ M. Nur Rianto al-Arif, Lembaga Keuangan Syariah: Suatu Kajian Teoritis Praktis (Bandung: Penerbit Pustaka Setia, 2012), 24.

${ }^{13}$ Irwandar, Dekonstruksi Pemikiran Islam (Yogyakarta: Ar-Ruzz Media Press, 2003), 41.

${ }^{14}$ Badruddin Bhat, Miskawayh on Society and Government Islamic Studies (Oxford: Clarendon Press, 1985), 29.
} 
Perilaku dan Budaya Konsumen Madura

dalam Dinamika Etika Bisnis Syariah

Dinamika budaya di masyarakat memunculkan pola dan aktivitas ekonomi, seperti industri, mekanisme pasar, hingga pada perlindungan konsumen dalam persaingan pasar. Pasar dengan segala permasalahannya kadangkala kurang memandang kepentingan dari sisi konsumen. Sehingga pada perkembangan selanjutnya mulai muncul pemikiran konsep pendekatan konsumen. Melalui budaya pendekatan konsumen maka pihak perusahaan atau pemasar dapat merumuskan suatu nilai-nilai kebaikan organisasional dan konsumen.

Tidak dapat dipungkiri bahwa agama bagi orang Madura adalah Islam yang sudah meresap dan mewarnai pola kehidupan sosial mereka. Agama merupakan hal yang sakral yang harus dibela dan merupakan pedoman hidup bagi manusia. Siapapun yang menghina agama harus mati. Salah satu sifat yang mendefinisikan bahwa orang Madura adalah pasti beragama Islam. Menurut mereka, urusan agama dikemukakan dalam ungkapan abhantal syahadat, asapo' iman, apajung Allah Azza wa Jalla, yang menggambarkan bahwa orang Madura itu berjiwa agama Islam. Menghina agama adalah sama dengan menyinggung harga diri. $^{15}$

Terdapat empat dasar citra diri masyarakat Madura, yaitu Islam, Kesopanan, kehormatan, dan kerja sama. Agama Islam sangat mempengaruhi segala seluk-beluk kehidupan sehari-hari orang Madura. Agama menjadi latar belakang pada kehidupan sosial lain yang memberi dukungan sanksi sakral pada kehidupan. Oleh karena itu, yang menghina agama harus mati, karena penghinaan terhadap agama sekaligus merupakan penghinaan kepada sanksi pendukung sosial. Sanksi itu menyebabkan mereka disebut "berjiwa Islam", dan sanksi ini merupakan salah satu faktor yang mendukung terus berlakunya nilai-nilai ini.

Guna menganalisis nilai-nilai kesukuan dalam kehidupan budaya etnis tertentu, definisi dari Glazer dan Moynihan menjelaskan bahwa kesukuan adalah yang digambarkan secara subyektif oleh kelompok etnik tertentu. Hal ini biasanya didasarkan pada bagaimana individu anggota kelompok etnik memberikan penilaian tentang dirinya. Fenomena yang dijadikan

${ }^{15}$ Soegianto, Kebudayaan Madura: Kepercayaan, Magi, dan Tradisi dalam Masyarakat Madura (Jember: Penerbit Tapal Kuda, 2003), 20. 
dasar untuk mengkaji hal ini adalah bahasa, rasa kebangsaan, agama dan kepercayaan, ras, kesenangan, dan sentiment perasaan pada kelompok. Lebih jauh kajian ini sering mengungkapkan tentang rasa etnosentrisme suatu kelompok. ${ }^{16}$

Orang Madura menganggap kehidupannya dilandasi oleh kerja sama (song-osong lombhung), bukan saja sebatas pada keluarga tetapi juga termasuk tetangga. Kerja sama dan gotong royong merupakan ciri kehidupan sosial masyarakat Madura, terutama di daerah pedesaan. Kerja sama ini dikatakan didasari oleh ajaran yang mewajibkan mereka untuk selalu saling membantu dan tolong menolong agar selamat. Jika tidak, hidupnya tidak diberi kebahagiaan oleh Tuhan. Hal ini terungkap dalam saloka "namen maghi tombu sokon, tabing kerrep bannya' karana. Pompong ghi' odi parokon ma' salamet odi'na". ${ }^{17}$

Salah satu nilai budaya lainnya yang tak kalah penting pada orang Madura adalah bahwa kesopanan dijunjung tinggi. Orang yang tidak sopan dianggap kurang ajar dan ia dapat cemoohan atau cercaan sebagai sanksi sosial. Walaupun orang luar sering menganggap bahwa orang Madura itu kasar, tetapi orang Madura sendiri menilai bahwa aturan kesopanan itu tinggi sekali, dan mereka menghargai orang yang mengikutinya. Ungkapan lain untuk orang yang tidak tahu atau melanggar adat kesopanan adalah ta'tao battona langghar (tidak pernah merasakan lantainya langgar). Maksudnya adalah bahwa orang tersebut tidak pernah masuk langgar dan mengaji ke pesantren sehingga ia tidak tahu tata krama kesopanan. ${ }^{18}$

Orang Madura bersikap tidak mau diremehkan tetapi terhadap penonjolan diri juga tidak dihargai. Perilaku dipengaruhi oleh situasi yang dihadapi. Jika orang yang dihadapi itu umpamanya sombong, besar kepala, dan menonjolkan diri, orang lain akan berusaha untuk lebih tinggi atau lebih sombong dari pada lawannya; ia cenderung untuk tidak mau kalah. Sebaliknya, jika orang yang dihadapinya itu bersahaja, merendah, dan menghargai orang lain, ia akan bersikap merendah pula. Mereka

${ }^{16}$ Glazer, N and Moynihan, Ethnicity: Theory and Experience (Cambridge: Harvard University Press, 1984), 1-26.

${ }^{17}$ Soegianto, Kebudayaan Madura: Kepercayaan, Magi, dan Tradisi dalam Masyarakat Madura, 22

${ }^{18}$ Ibid., 23. 
Perilaku dan Budaya Konsumen Madura

dalam Dinamika Etika Bisnis Syariah

mendefinisikan sifat ini sebagai maddhu ben dere (madu dan darah), Artinya bila orang Madura diperlakukan baik, menjunjung tinggi nilai penghormatan dan kesopanan maka balasannya adalah kebaikan pula, yang disamakan dengan manfaat madu yang diberikan lebah. Sebaliknya bila diperlakukan sembrono, balasannya lebih buruk bahkan dapat menimbulkan pertumpahan darah, lebih-lebih jika menyinggung perasaan dan kehormatan keluarga. Hal itu tercermin dalam saloka jha' nobi' oreng mon aba'na etobi' sake'. ${ }^{19}$

Masyarakat Madura yang sensitif dan fanatik terhadap nilainilai keagamaan; seperti kesopanan, saling menghormati, serta suka tolong-menolong berdampak konstruktif dengan nilai-nilai yang terkandung dalam prinsip-prinsip etika bisnis syariah. Dalam pembahasan tentang prinsip-prinsip dan etika berbisnis dalam Islam, Yusuf Qardlawi menjelaskannya sebagai berikut; ${ }^{20}$

1. Menegakkan larangan memperdagangkan barang-barang yang diharamkan.

2. Bersikap benar, amanah, dan jujur.

3. Menegakkan keadilan dan mengharamkan bunga.

4. Menerapkan kasih sayang dan mengharamkan monopoli.

5. Menegakkan toleransi dan persaudaraan.

6. Berpegang pada prinsip bahwa perdagangan adalah bekal menuju akhirat.

Apa yang disampaikan Yusuf Qardlawi ini menjadi landasan para pelaku bisnis syariah baik sebagai cermin perilaku individu maupun sebagai organisasi. Sebab perilaku individu pelaku bisnis syariah akan membentuk perilaku organisasi bisnis syariah yang pada akhirnya menjadi budaya organisasional institusi bisnis syariah.

Pembahasan nilai-nilai budaya dan agama secara organisasional berbeda dengan pembahasan etika individu sebagai muslim. Pembahasan etika individu mengutamakan pokok kajiannya pada perilaku seorang muslim dalam melakukan kegiatan ekonominya, sedangkan kajian etika organisasional bisnis

${ }^{19}$ Ibid.

${ }^{20}$ Yusuf Qardhawi, Norma dan Etika Ekonomi Islam (Jakarta: Gema Insani Press, Cet.

4, 2001), 173. 
syariah menitik-beratkan bahasannya pada unsur-unsur yang membentuk budaya organisasi bisnis syariah itu sendiri.

Oleh karena itu institusi bisnis syariah senantiasa merencanakan konsep organisasionalnya dengan teliti serta memperhatikan dan melibatkan persepsi konsumen dalam merancang sistem komunikasinya.

Perencanaan pengembangan institusi bisnis syariah yang berkaitan dengan konsep dan pelayanan konsumen, yaitu antara lain; ${ }^{21}$

1. Penciptaan nilai dalam bisnis syariah.

2. Pengelolaan aset secara professional oleh ahlinya.

3. Amanah dalam memelihara aset umat.

Penciptaan nilai dalam bisnis syariah adalah meliputi uji kepantasan dan kelayakan terhadap produk atau jasa yang dibisniskan, sehingga apa yang dijamin halal dan memberikan nilai kebaikan kepada konsumen. Begitu juga dengan akad-akad yang digunakan harus memenuhi aturan-aturan syariah dalam AlQur'an, Hadith, Ijma', serta Qiyas yang telah dikuatkan dan dilembagakan oleh Dewan Syariah Nasional.

Sedangkan yang dimaksud pengelolaan aset secara professional adalah bagaimana instutusi perusahaan mengintegrasikan Sumber Daya Manusia yang kompeten dalam manajemen dan hukum Islam (syariah mu'amalah). Artinya, sangat disayangkan apabila terdapat insitusi berlabel lembaga bisnis syariah justru tidak memiliki SDM yang benar-benar paham tentang syariah muamalah terkait produk atau jasa yang dijual.

Adapun pengertian amanah dalam memelihara aset umat yaitu bahwa instutusi bisnis syariah menjamin keamanan aset nasabah sesuai dengan akad yang telah dibuat dan disepakati oleh masingmasing pihak di awal kerja sama. Jika akad tersebut investasi maka jaminan yang diperlukan adalah bahwa aset tersebut untuk membiayai suatu proyek bisnis halal yang memberikan prospek nilai tambah (hasil) bagi kedua belah pihak. Sedangkan jika akad tersebut merupakan akad titipan/kepercayaan maka jaminan yang harus diberikan adalah bahwa nilai titipan aman dan tidak berkurang.

${ }^{21}$ Yan Orgianus, Moralitas Islam dalam Ekonomi \& Bisnis (Bandung: Penerbit Marja, 2012), 90, 179. 
Perilaku dan Budaya Konsumen Madura

dalam Dinamika Etika Bisnis Syariah

Dalam aspek pemikiran mengenai praktik ekonomi syariah sebagai perbandingan dengan ekonomi konvensional, ada tiga hal utama yang menjadi ciri khasnya. Pertama, praktik transaksi keuangan yang adil dan sistem bunga. Kedua, pemikiran mengenai proporsi distributif dan implikasi kebijakannya. Ketiga, pemikiran mengenai landasan moral dalam setiap kegiatan dan keputusan ekonomi. ${ }^{22}$ Dengan kata lain, ketiga klasifikasi pandangan ini menitik-beratkan pada pesan moral yang diajarkan dalam agama Islam.

\section{E. Penutup}

Perilaku adalah sebagai salah satu faktor yang membentuk suatu kebudayaan dalam etnis masyarakat tertentu. Masing-masing kekuatan baik dari aspek psikologis individu maupun kekuatan pengaruh kelompok sosial dalam masyarakat tersebut akan saling mengisi persepsi seseorang. Pada akhirnya, masing-masing persepsi individu ini juga akan membentuk persepsi sosial yang diyakini kebenarannya sebagai nilai budaya. Demikian halnya dengan budaya masyarakat Madura yang cenderung fanatik dengan nilai-nilai kemanusiaan, berkorelasi konstruktif dengan nilai-nilai etika bisnis syariah. Prinsip-prinsip bisnis Islami baik secara individu atau kelembagaan mengajak pada nilai-nilai professionalitas, kejujuran (amanah), persaudaraan dan keadilan, serta dilarang monopoli dan praktek riba. Oleh karena itu merealisasikan dan mengembangkan nilai etika bisnis syariah dalam budaya konsumen masyarakat Madura lebih mudah diterima sebab budaya masyarakat Madura pada dasarnya sangat memperhatikan nilai-nilai kesopanan, saling menghormati, serta suka tolong-menolong atau kerukunan.

${ }^{22}$ M. Nur Rianto al-Arif, Lembaga Keuangan Syariah: Suatu Kajian Teoritis Praktis, 50. 


\section{DAFTAR PUSTAKA}

Al-Arif, M. Nur Rianto. Lembaga Keuangan Syariah: Suatu Kajian Teoritis Praktis. Bandung: Penerbit Pustaka Setia, 2012.

Bhat, Badruddin. Miskawayh on Society and Government Islamic Studies. Oxford: Clarendon Press, 1985.

Bungin, H.M. Burhan. Sosiologi Komunikasi. Jakarta: Prenada Media, 3013.

Fakhry, Majid. Etika dalam Islam, terj. Zakiyuddin Baidhawy. Yogyakarta: Pustaka Pelajar, 1996.

Fauzia, Ika Yunia. Etika Bisnis dalam Islam. Jakarta: Prenada Media, 2013.

Glazer, $\mathrm{N}$ and Moynihan, Ethnicity: Theory and Experience. Cambridge: Harvard University Press, 1984.

Harahap, Sofyan Syafri. Akuntansi Islam. Jakarta: Bumi Aksara, 2001.

Irwandar. Dekonstruksi Pemikiran Islam. Yogyakarta: Ar-Ruzz Media Press, 2003.

Mangkunegara, Anwar Prabu. Perilaku Konsumen, edisi revisi.

Bandung: Refika Aditama, 2012.

Orgianus, Yan. Moralitas Islam dalam Ekonomi \& Bisnis.

Bandung: Penerbit Marja, 2012.

Qardhawi, Yusuf. Norma dan Etika Ekonomi Islam. Jakarta: Gema Insani Press, 2001.

Setiadi, N.J. Perilaku Konsumen: Konsep dan Implikasinya untuk Strategi dan Penelitian Pemasaran. Jakarta: Prenada Media, 2003. 
Perilaku dan Budaya Konsumen Madura

dalam Dinamika Etika Bisnis Syariah

Soegianto, Kebudayaan Madura: Kepercayaan, Magi, dan Tradisi dalam Masyarakat Madura. Jember: Penerbit Tapal Kuda, 2003.

Susilo, Rakhmad K.Dwi. Sosiologi Lingkungan. Jakarta: Rajawali, 2008.

Suwarman, Ujang. Perilaku Konsumen: Teori dan Penerapannya dalam Pemasaran. Bandung: Ghalia Indonesia, 2015.

Syukur, Suparman. Etika Religius. Yogyakarta: Pustaka Pelajar, 2004.

Warde, Ibrahim. Islamic Finance: Keuangan Islam dalam Perekonomian Global terj. Andriyadi Ramli. Yogyakarta: Penerbit Pustaka Pelajar, 2009. 